\title{
STUDY OF TSUNAMI MITIGATION BASED ON VEGETATION IN SERENTING BEACH, MANDALIKA SPECIAL ECONOMIC ZONE, LOMBOK ISLAND
}

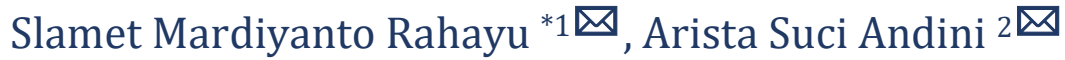 \\ ${ }^{* 1,2}$ Department of Biology, Faculty of Mathematics and Natural Sciences, Universitas Islam Al- \\ Azhar, NTB 83237, Indonesia
}

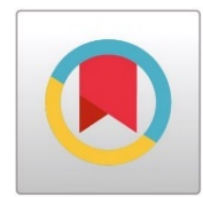

DOI: https://doi.org/10.29121/granthaalayah.v8.i12.2020.2473

Article Type: Research Article

Article Citation: Slamet Mardiyanto Rahayu, and Arista Suci Andini. (2020). STUDY OF TSUNAMI MITIGATION BASED ON VEGETATION IN SERENTING BEACH, MANDALIKA SPECIAL ECONOMIC ZONE, LOMBOK ISLAND. International Journal of Research GRANTHAALAYAH, 8(12), 60-68. https://doi.org/10.29121/granthaa layah.v8.i12.2020.2473

Received Date: 17 November 2020

Accepted Date: 25 December 2020

Keywords:

Mandalika

Serenting Beach

Tsunami Mitigation

Vegetation

\section{ABSTRACT}

Serenting Beach is one of the beaches in the Mandalika Special Economic Zone (MSEZ), Central Lombok Regency. The MSEZ is located in the southern part of Lombok Island and faces the Indian Ocean. The Mandalika Special Economic Zone is prospected to expedite the sector of tourism at Province of West Nusa Tenggara which is very potential. A few hundred kilometers to the south part of Lombok Island is one of the large tectonic plates meeting zones which is a major source of potential tsunami earthquakes. With the geological conditions of Lombok Island which is prone to tsunamis and the existence of environmental degradation in Serenting Beach, MSEZ, it is necessary to conduct research about study of tsunami mitigation based on vegetation in Serenting Beach, MSEZ, Lombok Island. Based on the research, there are several types of plants that need to be planted as a tsunami disaster mitigation effort in Serenting Beach, MSEZ, namely: Casuarina equisetifolia, Pandanus odoratissimus, Cocos nucifera, Hibiscus tiliaceus, and Terminalia catappa. The government and various related parties need to provide education to the public, tourism managers, and tourists to take an active role in protecting vegetation and not through illegal logging.

\section{INTRODUCTION}

The beach is a natural potential that is often used as a tourist attraction. Indonesia, with its diverse natural wealth and its tens of thousands of islands, certainly has many beaches [1]. Coastal is an area that has an important function for human activities. This area often functions as a settlement, industry, port, aquaculture, agriculture and tourism [2]. Serenting Beach is one of the beaches in the Special Economic Zone (MSEZ) of Mandalika. The Special Economic Zone (MSEZ) of Mandalika is a National Strategic Project and one of the Special Eonomic Zonez (SEZs) developed by the Government of Indonesia, in collaboration with the Provincial Governments of West Nusa Tenggara and Regency of Central Lombok in the Tourism Sector to accelerate the growth of this sector in Province West Nusa Tenggara [3]. MSEZ is part of Central Lombok with an area of 1,035.67 hectares and overlooks the Indian Ocean. MSEZ is prospective to expedite the tourism development in Province of West Nusa Tenggara which is very promising [4]. 
MSEZ proffer maritime tourism offering stunning beach and charming underwater. Each year, the community at Central Lombok commemorate the Bau Nyale ceremonial, which is a ceremonial that collecting sea worms which is believed to be the incarnation of Princess Mandalika. This ceremonial is a unique local culture and draws both internationa and local tourist. MSEZ has an environmentally tourism development concept with the development of tourism objects and attractions that are oriented towards the environmental values preservation and communities quality [4].

Indonesia, Sri Lanka, India and the Maldives are countries that are prone to tsunami disasters [5]. The MSEZ is located in Central Lombok Regency, located on the island of Lombok, West Nusa Tenggara Province, Indonesia. Several hundred kilometers to the south part of Lombok Island lies one of the junction zones of large tectonic plates, which are the main source of earthquakes with the potential for tsunamis. Lombok is also vulnerable to tsunamis from the back arc fault, which faces the northern part of Lombok Island. The frequency of shallow and large earthquakes in Nusa Tenggara is relatively high, naturally there is a potential risk of a tsunami affecting the southern and northern coastal areas of West Nusa Tenggara. Apart from the subduction zones of the Sunda Fault and the Back Arc Fault, two other sources of tsunami hazard have been identified, namely underwater landslides and volcanic activity. Underwater landslides are often associated with earthquakes. If an avalanche occurs during an earthquake, it can increase the tsunami energy and therefore increase the lift effect by tectonic movements in the subduction zone or back arc (also caused by earthquakes) [6].

Tsunami disasters that can occure naturally and cause major damage that endangers human life and socioeconomic conditions [7]. There has been an earthquake accompanied by a large tsunami in several areas in Indonesia, such as in Palu Bay [8], Aceh [3], [9], [10] and Banten [11]. Based on this, efforts to reduce or minimize the impact caused by the tsunami considering its very large destructive nature are very important. Based on the Home Affairs Ministry Regulation No. 33 of 2006 regarding Prevalent Guidelines for Disaster Mitigation means that disaster mitigation activities in the regions are bring out to specify the prospect for disasters in the area and to anticipate their handling. Risk reduction through mitigation is carried out before a disaster occurs, so that the community can avoid disaster risk [12].

Over the past twenty years, some shattering tsunami have increased the consciousness of coastal communities about the impact that tsunamis have. This has sparked debate about a nature-based approach to tsunami disaster mitigation [13], [8], [14]. Environmental-based breakthrough are important to sustain risk managementat coastal part [15]. Insecurity will the tsunami disaster make the coastal area a must has a natural buffer in the form of a good coastal forest to minimize the effects of the tsunami attack [16]. There have been several studies investigating the role of vegetation in tsunami run-off [17], [18]. Coastal vegetation is an alternative in tsunami mitigation. This alternative is sufficient both from an economic point of view, especially in developing countries like Indonesia [19]. Coastal vegetation recognized widely as a natural method as tsunami's wave energy reducer. Coastal vegetation showed great potential in mitigating the damage caused by tsunami significantly in developed areas and also saving human lives with functioning as buffer zones during natural disaster at coastal area. However, a barrier that made of vegetation not enough to stop a tsunami completely, its effectiveness depends on structure of the vegetation and extremity of the tsunami [20]. Other researcher did a laboratory experiment to analyzed various combination and the effect of vegetation barrier. They observed that the barrier acts as a buffering zone when the waves pass through the vegetation barrier and made the wave height decreases as it passes through the vegetation barrier [21].

Vegetation is a combination of various types of plants that grow in a certain area. Differences in the environment in which plants live will provide different vegetation patterns [22]. Serenting Beach, MSEZ has a diversity of vegetation that has been degraded due to land conversion into tourist areas, settlements, and various other anthropogenic activities. It is feared that this will reduce the capacity and resilience of the area if there is a high wave (tsunami). With the geological condition of Lombok Island which is prone to tsunamis and environmental degradation on Serenting Beach, MSEZ, it is necessary to conduct research in the form of a vegetation-based tsunami mitigation study on Serenting Beach, MSEZ 


\section{MATERIALS AND METHODS}
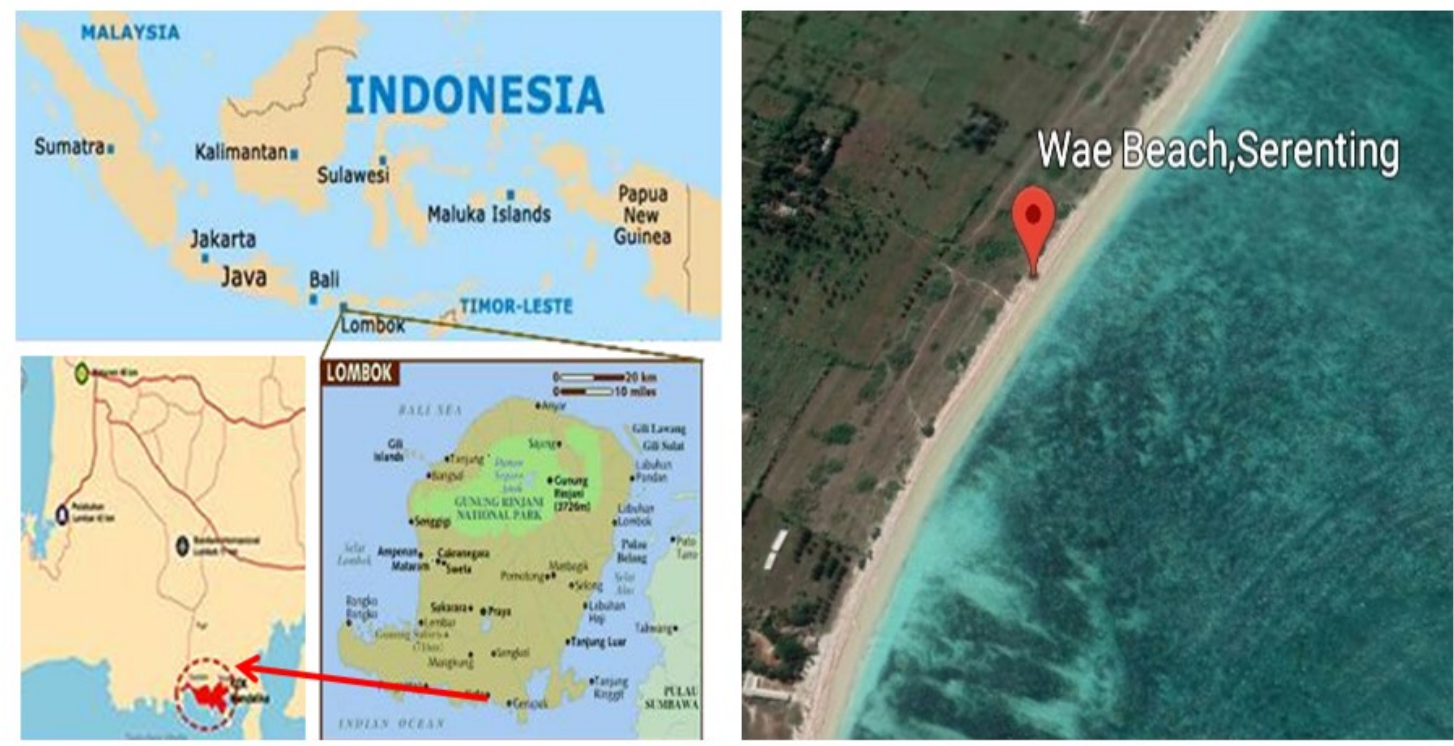

Figure 1: Research location on Serenting Beach (854'25"S 116 $18^{\circ} 21^{\prime \prime}$ E); and the detected sites

Number of rainy days per month in MSEZ, Lombok Island ranges from 1 to 26 days with rainfall ranging from $0.4 \mathrm{~mm}$ to $448.3 \mathrm{~mm}$. The research was conducted using the exploration method (roaming) at Serenting Beach, MSEZ, Central Lombok Regency. The research was carried out by listing the types of plants suitable for planting as a vegetation-based tsunami disaster mitigation effort on Serenting Beach. Identification of plant species refers to The Book of Flora [23] and the Guide to Introduction to Mangroves in Indonesia [24].

Mandalika Special Economic Zone (MSEZ), Lombok island has a tropical climate with a dry summer. The rainy season is quite high throughout the year. The results of the research were then analyzed descriptively.

\section{RESULTS AND DISCUSSIONS}

The southern coast of Lombok Island, such as Serenting Beach, MSEZ, is an open sea which directly faces the Indian Ocean. Serenting Beach faces various problems such as unplanned development, population growth, and various impacts of global climate change and is vulnerable to disasters such as tsunamis.

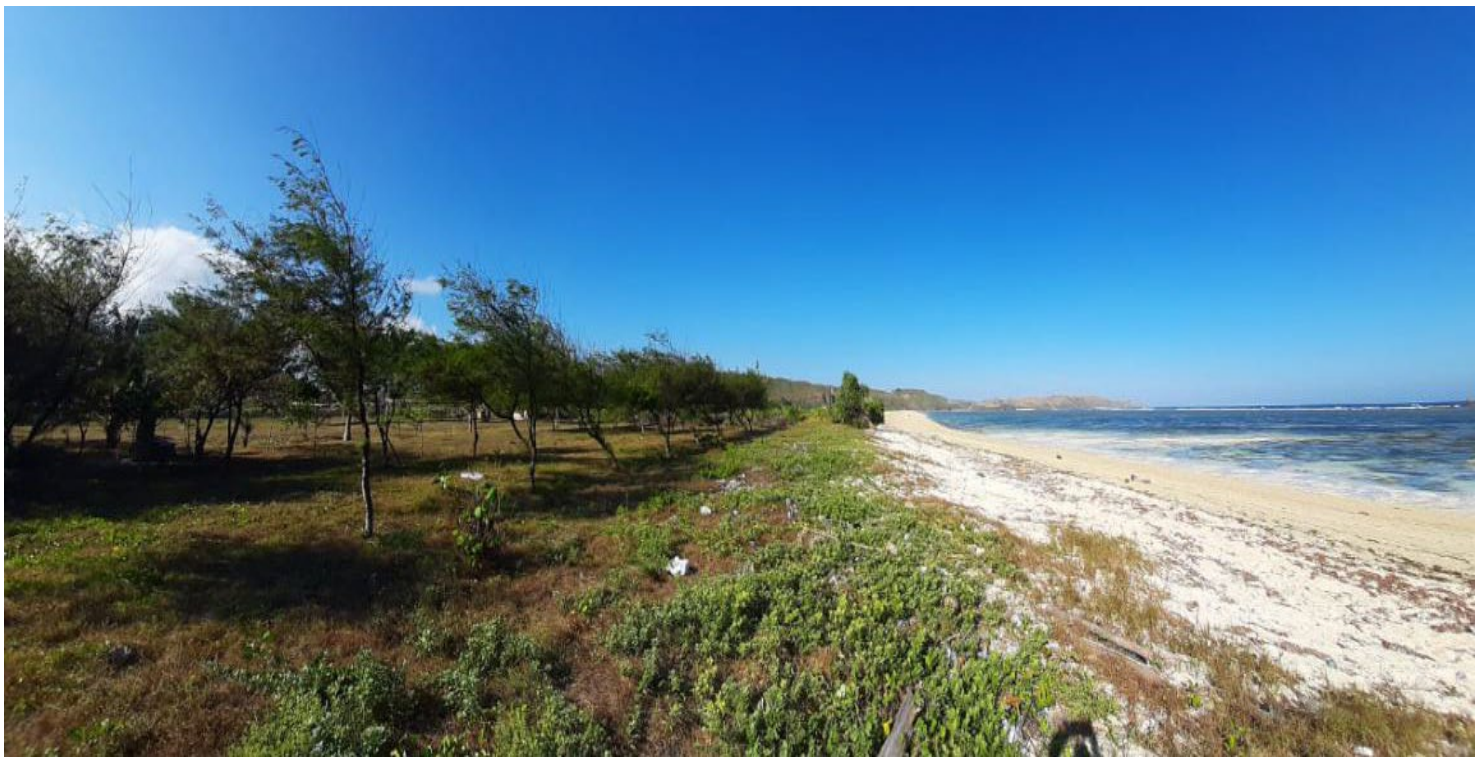

Figure 2: Vegetation on Serenting Beach, Mandalika Special Economic Zone (MSEZ) 
There are several types of plants that have the potential to mitigate the tsunami disaster on Serenting Beach, MSEZ, namely: Casuarina equisetifolia, Pandanus odoratissimus, Cocos nucifera, Hibiscus tiliaceus, and Terminalia catappa.

Table 1: Types of Plants at Serenting Beach

\begin{tabular}{|c|c|}
\hline Vegetation & Density (Individual /hectare) \\
\hline Hibiscus tiliaceus & 333 \\
\hline Ipomoea pescaprae & 29167 \\
\hline Cyperus rotundus & 43750 \\
\hline Robinia pseudoacacia & 250 \\
\hline Euphorbia serpens & 31250 \\
\hline Calotropis gigantea & 16552 \\
\hline Pandanus odoratissimus & 467 \\
\hline Cocos nucifera & 300 \\
\hline Casuarina equisetifolia & 1533 \\
\hline Terminalia catappa & 480 \\
\hline
\end{tabular}

Coastal areas such as Serenting Beach, MSEZ, Lombok Island are characterized by strong wind conditions and contain salt, even occasionally inundated with sea water. The strong sea breeze to land with a salt content causes the salt content of the sandy soil around the coast to be higher than in inland areas. The soil salt content will decrease the farther from the coast. The dominant sand in the coastal area causes plants that can survive are drought-resistant plants. These herbs can survive especially in the dry season with minimal humidity or night dew.

Density (Individu/hectare)

$$
\begin{array}{r}
1800 \\
1600 \\
1400 \\
1200 \\
1000 \\
800 \\
600 \\
400 \\
200 \\
0
\end{array}
$$

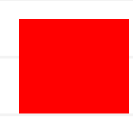

Hibiscus tiliaceus

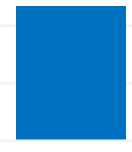

Pandanus odoratissimus

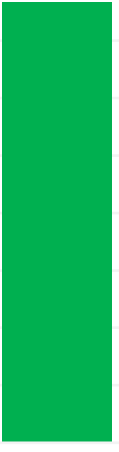

Cocos nucifera
Casuarina equisetifolia

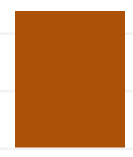

Terminalia catappa

Figure 3: Densities of indivdual plant species potentially in tsunami mitigation at Serenting Beach

Configuration of coastal vegetation with a certain thickness and density will form a coastal belt that provides many benefits to the environment and society. Coastal vegetation has an important role in the development of coastal communities and protecting the coastal environment. The extent, density, age and height of coastal vegetation can reduce the negative impact of a tsunami. Some vegetation functions when a tsunami occurs, for example as a softlanding effect, trapping effect, and escaping effect. The important of coastal vegetation can be observed at Figure 4. 

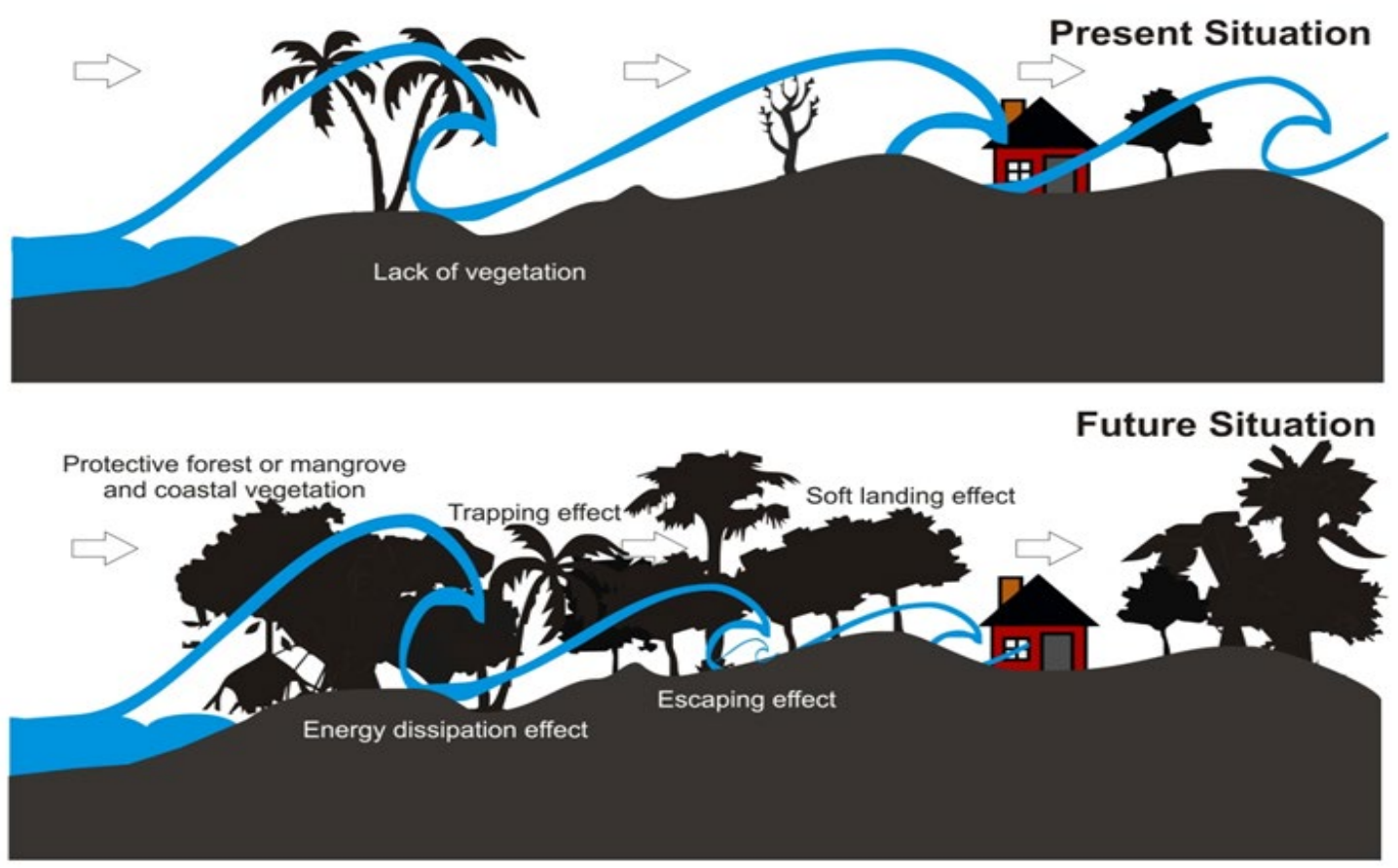

Figure 4: The function of vegetation during a tsunami

Based on the research there are ten (10) types of plants on Serenting Beach, namely: Hibiscus tiliaceus, Ipomoea pescaprae, Cyperus rotundus, Robinia pseudoacacia, Euphorbia serpens, Calotropis gigantea, Pandanus utilis, Cocos nucifera, Casuarina equisetifolia, and Terminalia catappa. The ten plants can be planted in such a way as to form a park called a tsunami mitigation park. Tsunami mitigation parks are one approach in tsunami mitigation based on nature. Tsunami mitigation parks are built to protect critical infrastructure or at-risk communities behind the park [15].

The Casuarina equisetifolia plant has a habitus in the form of a evergreen tree with a height of 6-35 m. This plant has the bark of a light gray brown, leathery, and old tree grooved with lenticel rings clearly visible on the young bark. The branches droop, the leaves are like needles arranged in 7-8 strands. Male flowers are located at the end, in the form of elongated ears. Female flowers are compound cone, round. The fruit is gray or yellow brown. C.equisetifolia is able to grow on light, sandy soils, grows fast on thin soils and is tolerant of salt soils and salt winds. It grows well on soils with a pH of 5.0-9.5, is not resistant to tides, does not tolerate shade and is sensitive to fire.

The type of plant that is most often planted as a tsunami damper in coastal areas is C. equisetifolia. This is because C.equisetifolia grows fast and can adapt well to the coastal environment. C.equisetifolia along the coast served as a protective fortress from the tsunami. The C.equisetifolia forest is also a place for the development of animals that are very sensitive to signs of a tsunami, so that they can signal to the community that a tsunami will be coming [25]. C.equisetifolia will be able to withstand strong winds, crashing sea waves, and rolling sand along Serenting Beach, MSEZ. Therefore, C.equisetifolia is very well used as a windbarrier in coastal areas that are vulnerable to the danger of strong winds and tsunamis, such as in Serenting Beach, MSEZ. [26] completed a model using 7 years old of Casuarina equisetifolia and concluded that trees with high density in Bay at Pacitan measurement results can decrease the speed and height of tsunami's waves that drove up to the mainland. The rate at which it reduces depends on the density of the trees, the lenght of coastal forest, and also the height of tsunami's waves.

Apart from playing a role in tsunami mitigation, C.equisetifolia forests are very good for making land around the coast productive. The tightness of $C$. equisetifolia leaves can prevent the salt area around the coast from spreading. C.equisetifolia trees are able to neutralize winds from oceans containing high salinity. In addition, hot air in coastal areas can be cooled by the coolness of oxygen produced by C.equisetifolia trees. Storms carrying heavy sand can also be blocked by the branches of the $C$. equisetifolia tree so they don't damage the plants. And of course, makes Serenting Beach in the MSEZ shady and cool. Tourists visiting Serenting Beach, MSEZ can take shelter while looking at the panoramic view of the Indian Ocean. 
Based on [20], C. equisetifolia dense growing on beach sand proved to be very effective in providing protection from tsunami damage due to its density and complex air root structure. [27] examine the disaster at Papua New Guinea tsunami that caused by Tsunami in 1998 and obtained that Casuarina trees have comparatively greater resistance than palm trees. However, they point out the need for further research to understand the interaction of trees, roots, and high water waves in relation to the use of vegetation as tsunami mitigation as significant scouring occurs in areas where root systems are damaged, and in some cases, trees cause damage. addition to the surroundings due to the heavy water flow. This deficiency is also shown [28].

Pandanus odoratissimus plants are medium to large with a height of up to $15 \mathrm{~m}$. The roots are clearly visible, reaching a height of $1 \mathrm{~m}$ or more, with sharp internodes. Slightly waxy white leaves with tapered tips and spiny edges. [28] and [18] stated that the Pandanus odoratissimus plant has many aerial roots so that it can remain upright when there is a tsunami with a height of less than $5 \mathrm{~m}$. This means that Pandanus is a plant that can play a role in tsunami mitigation. Coastal vegetation that consisted of Pandanus odoratissimus that growed densely on the very lenient ground slope could dissolve energy of the tsunami more efficiently rather than the same vegetation on the relatively steep ground slope. This case was analyzed by an enhanced one-dimensional numerical model quantitatively that included variated topography and tsunami characteristics [29].

Take into account the limitations of P.odoratissimus in reducing tsunami water depth and the other roles that coastal vegetation can play in reducing tsunami damage. The coastal forest consisting of a dense combination of $P$. odoratissimus and $C$. equisetifolia plants is a good tsunami mitigation effort. Combined planting of P.odoratissimus and C.equisetifolia has been shown to be effective in increasing resistance and trapping floating debris in Kalutara, Sri Lanka [20].

C. nucifera is a humid tropical plant. It is quite adaptable to differences in temperature and water supply and is still common in areas near ecological zone boundaries. $C$. nucifera thrives in a variety of soils, if adequate drainage and aeration are present. C. nucifera is halophytic and well tolerant of salt. Can grow at a wide range of pH but grows best at pH 5.5-7. C. nucifera plants have stems that can reach $15 \mathrm{~m}$ high. Fully open petals totaling 30-40 leaves, leaf length ranging from 5-7 meters, first flowering ranges from 7-10 years after planting. The fruit of this plant ripens about 12 months after pollination.

C. nucifera is a tree species that is strong against the tsunami. $C$. nucifera trees have been shown to be more effective at resisting waves. In Kerala, India, densely planted $C$. nucifera gardens protect the coast [4]. A combination of different tree species is recommended in a forest for tsunami mitigation efforts. P.odoratissimus has been observed to grow under stands of $C$. nucifera and C. equisetifolia [29].

Hibiscus tiliaceus usually grows along the coast (such as in Serenting Beach) and near tidal currents. Based on its ecology, H.tiliaceus is usually found in secondary lowland forests and barren areas. H.tiliaceus is often found in humid areas and along rivers. Hibiscus tiliaceues has a tree habitus and can reach $15 \mathrm{~m}$ high and the bark is grayish brown. Leaves shaped like a heart with a tapered tip. The lower surface of the leaves is smooth and slightly white. Bell-shaped flowers are located in the axillary of the leaves with yellow petals.

Mitigation effects on a simulated coastal forest with Hibiscus tiliaceus trees in Sissano, Papua New Guinea show substantial reductions in inundation depth and hydraulic strength. The maximum reduction in hydraulic force for a single site is $275,000 \mathrm{~N} / \mathrm{m}$ to $900,000 \mathrm{~N} / \mathrm{m}$, or about $67 \%$ reduction, with forest barrier of four large H.tiliaceus trees per $100 \mathrm{~m}^{2}$ [30].

The Terminalia catappa plant has a shady trunk with branches that grow horizontally and are stratified. Leaves scattered, mostly crammed at the ends of twigs, short-stemmed or nearly seated. Upside-down round egg-shaped leaf blade with a smooth top surface of the leaf and the underside of the leaf has fine hair and is reddish in color when it falls out. Flowers are small, collected in a spike near the end of the twig. The fruit is ovoid, faceted or narrowwinged. Coastal forest plant species such as Terminalia catappa with a height ranging from 25-40 m can play a role in tsunami mitigation.

In an effort to suppress casualties and economic and social losses then must conducted tsunami disaster mitigation continuous and continuous so that awareness is formed in the community especially coastal residents for always be aware of the tsunami disaster and do not panic when faced with events tsunami and can save yourself. Besides being educational and awareness society towards the environment and potential the danger that exists, then mitigate it regularly structural must also be done. Some natural forms of landscapes such as coastal forests can naturally dampen tsunami waves so the waves are reaching the shore can lower energy, altitude and penetration. 
In order to reduce the tsunami hazard and at the same time to protect coastal areas from the threat of abrasion, sea breeze, saltwater infiltration on land, absorb pollutants, and maintain coastal and marine productivity, it is necessary to create a coastal protection zone with forest development. mangrove or coastal forest [25].

Tree canopy plays a very important role in resisting tidal waves and backflow. Therefore, in tsunami mitigation at Serenting Beach, MSEZ, various types of tree plants and having certain canopy shapes need to be arranged and arranged in such a way as to both the types and the flow of planting, so that they act in layers as a buffer and breaker of tidal waves. In addition, in regulating these plants it is necessary to consider aesthetic factors so that the Serenting Beach area, MSEZ still has beauty and attractiveness. The paths of the plants are laid out in such a way as to produce a layered canopy in which the plants with the lower canopy are placed at the forefront and further back the higher canopy serves to break the tide and buffer backflow. The government and various related parties need to provide education to the community, tourism managers, and tourists on Serenting Beach, MSEZ to take an active role in maintaining coastal vegetation which plays a role in tsunami disaster mitigation and does not carry out illegal logging

\section{CONCLUSIONS AND RECOMMENDATIONS}

We can conclude that there are several types of plants that have the potential to mitigate the tsunami disaster on Serenting Beach, Mandalika Special Economic Zone (MSEZ), namely: Casuarina equisetifolia, Pandanus odoratissimus, Cocos nucifera, Hibiscus tiliaceus, and Terminalia catappa. The government and various related parties need to provide education to the community, tourism managers, and tourists on Serenting Beach, MSEZ to take an active role in maintaining coastal vegetation which plays a role in tsunami disaster mitigation and does not carry out illegal logging.

\section{SOURCES OF FUNDING}

This research received no specific grant from any funding agency in the public, commercial, or not-for-profit sectors.

\section{CONFLICT OF INTEREST}

The author have declared that no competing interests exist.

\section{ACKNOWLEDGMENT}

Thanks to the Institute for Research and Community Service of Al-Azhar Islamic University and the Directorate General of Research and Development Strengthening, the Ministry of Technology Research, and Higher Education which have provided grants for the implementation of this research.

\section{REFERENCES}

[1] Fani, M.P. 2018. Tanjung Aan Beach as tourist attraction in Central Lombok. Domectic Case Study 2018 Ambarrukmo Yogyakarta Tourism College: 1-10.

[2] Dhiauddin, R., Gemilang, W.A., Wisha, U.J., Rahmawan, G.A., and G. Kusumah. 2017. Mapping of Simeulue Island's Coastal Vulnerability Using the CVI (Coastal Vulnerability Index. EnviroScienteae 13 (2): 157-170.

[3] West Nusa Tenggara Province Financial and Development Supervisory Agency. 2018. Exotica Senggigi: Mandalika Got Us. Mataram: Financial Agency Supervision and Development of West Nusa Tenggara Province.

[4] National Council for the Special Economic Zones of the Republic of Indonesia. 2018. Profile of Mandalika Tourism Special Economic Zone. Jakarta: National Council for Special Economic Zones of the Republic of Indonesia.

[5] Shaw, R., Takeuchi, Y., Imura, M., Ogino, Y., Krishnamurty, R., Jayalaksmi, V., Lakshmi, A., Babu. S., Pribadi, K.S., Argo, T., Surjaningsih, R.D., Oetomo, A., Mariany, A., Ekawati, N., Parlan, H., Saptoadi, T., Nadapdap, J., Mildawty, M., Nianthi, R., Hennayake, S.K., Bandara, M., Nandalal, K.W., Herath, H.M.D.R., Bandara, R., Jayakumara, MAS., Nawfhal, A.S.M., Tennakoon, S.U.B., Alagan, R., Davendra, C,H., Jayasekara, S.R., Premasiri, S.M., Giragama, 
W.M.G.B., Jayasundara, S., Imbulana, L., Wijesinghe, M., and C. Perera. 2009. Building Resilience to Tsunami in the Indian Ocean. Japan: International Environment and Disaster Management Laboratory, Graduate School of Global Environmental Studies, Kyoto University.

[6] Mueck, M. 2013. Tsunami Hazard Maps for Lombok, Technical Document. Jakarta: GIZ International Services, Ministry of Research and Technology, Project for Training, Education and Consulting for Tsunami Early Warning System (PROTECTS) Capacity Development in Local Communities.

[7] Tanaka, N., Sasaki, Y., Mowjood, M.I.M., and K.B.S.N. Jinadasa. 2007. Coastal vegetation structures and their functions in tsunami protection: Experience of the recent Indian Ocean tsunami. Landscape and Ecological Engineering 3: 33-45.

[8] Muhari, A., Muck, M., and Spahn, H. 2012. Tsunami Mitigation Planning In Pacitan, Indonesia: A Review of Existing Efforts And Ways Ahead. Journal of Tsunami Society International 31 (4): 244-267.

[9] Lay, T., H. Kanamori, C.J. Ammon, Meredith Nettles, Steven N Ward, Richard C Aster, Susan L Beck, Susan L Bilek, Michael R Brudzinki, Rhett Butler, Hether R DeShon, Göran Eström, Kenji Satake, and Stuart Sipkin. 2005. The Great Sumatra-Andaman Earthquake of 26 December 2004. Science 308: 1127-1133.

[10] Subarya C., M. Chlieh, L. Prawirodirdjo, J.P. Avouac, Y. Bock, K. Sieh, A. Meltzner, and D.H. Natawidjaja. 2006. Plate-boundary deformation associated with the great Sumatra-Andaman earthquake. Science 440: 46-51.

[11] International Federation of Red Cross and Red Crescent Societies. 2018. Tidal Wave/Tsunami in Banten. Jakarta: International Federation of Red Cross and Red Crescent Societies.

[12] Ministry of Home Affairs of the Republic of Indonesia. 2006. Regulation of the Minister of Home Affairs No.33 of 2006 concerning General Guidelines for Disaster Mitigation. Jakarta: Ministry of Home Affairs of the Republic of Indonesia.

[13] Bayas, J.C.L, Marohn, C., Dercon, G., Dewi, S., Piepho, H.P., Joshi, L., Noordwijk, M.V., and G. Cadish. 2011. Influence of coastal vegetation on the 2004 tsunami wave impact in west Aceh. Proceedings of the National Academy of Sciences of the United States of America 108 (46): 18612-18617.

[14] Mukherjee, N., Dahdouh-Guebas, F., Kapoor, V., Arthur, R., Koedam, N., Sridhar, A., and K. Shanker. 2010. From Bathymetry to Bioshields: A Review of Post-Tsunami Ecological Research in India and its Implications for Policy. Environmental Management 46: 329-339.

[15] Lunghino, B., Tate, A.F. S., Mazereeuw, M., Muhari, A., Giraldo, F.X., Marras, S., and J. Suckale. 2020. The protective benefits of tsunami mitigation parks and ramifications for their strategic design. Proceedings of the National Academy of Sciences of the United States of America 117 (20): 10740-10745.

[16] Susanto, D., Faida, L. R. W., and Sunarto. 2019. Effectiveness Model of Coastal Forest in Pananjung Nature Reserve, Pangandaran as Tsunami Buffer. Journal of Forest Science 13: 4-14.

[17] Harada, K. and F. Imamura. 2005. Effects of coastal forest on tsunami hazard mitigation-A preliminary investigation" in Tsunamis. Springer: 279-292.

[18] Thuy, N.B., Tanaka, N., and K. Tanimoto. 2011. Tsunami mitigation by coastal vegetation considering the effect of tree breaking. Journal Coastal Conservation 16 (1): 111-121.

[19] Benazir, Triatmadja, R., Rahardjo, A.P., and N. Yuwono. 2018. The Implementation of Combined Roughness and Reflected Model (CRRM) in Tsunami Run-up Simulation through Coastal Vegetation. Journal of the Civil Engineering Forum 4 (3): 1-8.

[20] Tanaka, N. 2009. Vegetation Bioshields for Tsunami Mitigation: Review of the Effectiveness, Limitations, Construction, and Sustainable Management. Japan: Graduate School of Science and Engineering, Saitama University.

[21] Rahman, A. and Rahman, A. 2013. Effectiveness of coastal bio-shield for reduction of the energy of storm surges and cyclones. Procedia Engineering 56: 676 - 685.

[22] Henuhili, V., Sudarsono, Suyitno, dan T.Aminatun. 2010. The Diversity of Fauna and Flora at The Coast Samas and Glagah of Yogyakarta. National. Proceedings of the National Seminar on Biology: 118-127.

[23] Van Steenis, C. G. G. J. 2005. Flora. Jakarta: Pradnya Paramita.

[24] Noor, Y.R., Khazali M., dan I.N.N Suryadiputra. 2012. Guide to Introduction to Mangroves in Indonesia. Bogor: Wetlands International Indonesia Programme.

[25] Rahayu, S.M., Wiryanto, dan Sunarto. 2016. Tsunami Mitigation in Purworejo Regency, Central Java based on Vegetation Diversity. Fish Scientiae 6 (2): 63-79. 
Study of Tsunami Mitigation Based on Vegetation in Serenting Beach, Mandalika Special Economic Zone, Lombok Island

[26] Purwono, Novy, A.S., Nizam, and Triatmadja,R. 2017. Characteristics of High Growth Casuarina equisetifolia and High Inundation of Tsunami when Propagating through Greenbelt Vertical Rod. Applied Mechanics and Materials 862: 21-26

[27] Dengler, L. and J. Preuss. 2003. Mitigation lessons from the July 17, 1998 Papua New Guinea tsunami. Pure and Applied Geophysics 160: 2001-2031.

[28] Shuto, N. 1987. The effectiveness and limit of tsunami control forests. Coastal Engineering in Japan 30 (1): 143-153.

[29] Chadha, R. K., Latha, G., Yeh, H., Peterson, C. and T. Katada. 2005. The tsunami of the great Sumatra earthquake of M 9.0 on 26 December 2004 - impact on the east coast of India. Current Science 88 (8): 1297-1301.

[30] Hiraishi, T. and K. Harada. 2003. Greenbelt tsunami prevention in South Pacific region. Report of the Port and Airport Research Institute 42 (2): 1-23. 